\title{
IMAGENS NO SATYRICON: UM ENSAIO SOBRE ARS MEMORIAE
}

Caroline Morato Martins ${ }^{1}$

RESUMO: Este artigo discute as noções de memória e imagem na Antiguidade greco-romana. Analisamos essas noções nas obras selecionadas que se relacionam ao que tentamos entender como uma história da arte da memória antiga. Há inúmeras fontes que, talvez, pudessem compor um trabalho com intuito de pensar a história da arte da memória clássica, mas destacamos: Fedro (Platão), De Anima (Aristóteles), De oratore (Cícero), Rhetorica ad Herennium (sem autoria definida) e Naturalis Historia (Plínio, o Velho). Estas obras serão utilizadas para situarmos o uso de recursos ecfrásticos no Satyricon, obra atribuída a Petrônio, um cortesão do período neroniano, segundo Tácito (Ann. XVI, 18-19), elegantiae arbiter da corte de Nero. Salientamos o episódio da Cena Trimalchionis (25-78), devido à composição do retrato do rico liberto Trimalquião, descrições de sua casa e monumento e, posteriormente, o episódio ambientado em uma pinacoteca (83-89), devido à discussão sobre arte encarnada por Encólpio e Eumolpo, quando apresentaremos uma aproximação entre esta obra e a Naturalis Historia, justificada por uma concordância entre ambas relativa à arte ou à valoração que se dá à arte e pela denúncia de uma decadência moral e artística contemporânea. Entendemos que uma leitura adequada do Satyricon requer a elaboração de um panorama crítico e um estudo aprofundado da ars memoriae na Antiguidade, sendo essa a função do artigo.

PALAVRAS-CHAVE: Arte; Memória; Satyricon; Imagem.

ABSTRACT: This article discusses notions of memory and image in Greco-Roman Antiquity. I analyze these notions in selected texts related to what I understand as a history of art of ancient memory. Several texts could be the source of such a work, but I have chosen Phaedrus (Plato), De Anima (Aristotle), De oratore (Cicero), Ad Herennium (unknown author) and Naturalis Historia (Pliny, the Elder). This is because these works help to situate the use of ekphrastic resources in the Satyricon, the real focus of my analysis. The Satyricon was attributed to Petronius, a courtier during the Neronian period, whom according to Tacitus (Ann. XVI, 18-19) was the elegantiae arbiter of Nero's court. In the Satyricon, I particularly look at the Cena Trimalchionis (25-78), considering information regarding the composition of Trimalchio's portrait: his status as a rich freed man, descriptions of his house and the monument in his house. Subsequently, I also look at the discussions on art between Encolpius and Eumolpus during the episode set in a pinacotheca (83-89), when I will establish parallels between the Satyricon and the Naturalis Historia. With this, I hope to bring forward convergences which reveal an agreement about what is art or the value of art, and criticism regarding moral and artistic decline. I believe that an appropriate interpretation of the Satyricon requires the

${ }^{1}$ Mestranda da Universidade Federal de Ouro Preto, bolsista CAPES. Integrante do LEIR-UFOP. 
elaboration of a critical overview and a comprehensive study of ars memoriae in Antiquity, that being the main o objective of this article.

KEYWORDS: Art; Memory; Satyricon; Image.

\section{Precedentes da imagem na Antiguidade}

Francis Yates (2007) indicou uma associação entre a chamada teoria mnemônica e a teoria do conhecimento aristotélica. ${ }^{2}$ De acordo com a autora, Aristóteles, no seu De Anima, constrói postulações sobre a memória e a reminiscência que remontam à sua teoria do conhecimento, por ambas utilizarem e dependerem da imaginação ( avtaơia). Ao tratar da noção de memória e da teoria do conhecimento inseridas no pensamento aristotélico, primeiramente, devemos considerar uma relação intrínseca entre a imaginação

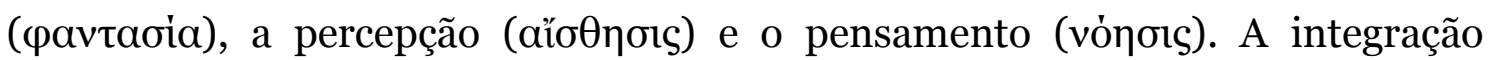
destas três noções estrutura o que podemos chamar de teoria aristotélica sobre o conhecimento:

Uma vez que definem a alma ( $\psi$ $\chi \eta ́ v)$ sobretudo a partir de duas diferenças, isto é, pelo

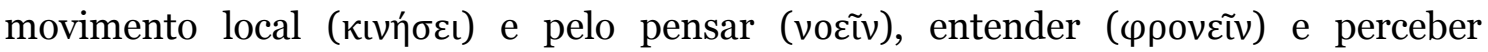
( $\alpha i \sigma \theta \alpha \dot{v \varepsilon} \sigma \theta \alpha \iota$ ), e como o pensar e entender parecem ser um certo perceber (pois em

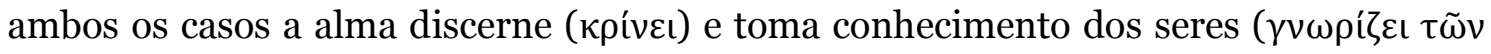

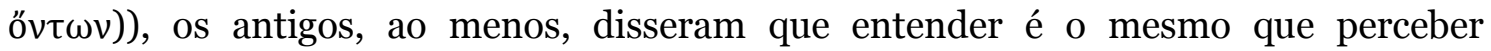
(Aristóteles, De Anima, III, 3, 427a17).

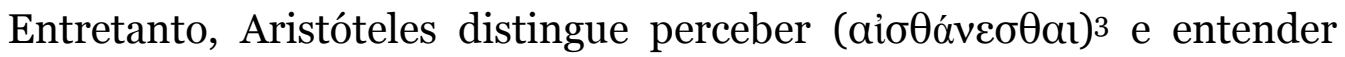

\footnotetext{
${ }^{2}$ Sobre a questão da chamada teoria mnemônica, Yates (2007, p.18) faz um importante alerta que é fundamental para já indicarmos o rumo que nossa discussão seguirá: "O estudioso da história da arte clássica da memória deve sempre lembrar que essa arte pertencia à retórica, como uma técnica que permitia ao orador aprimorar sua memória, o que o capacitava a tecer longos discursos de cor, com uma precisão impecável”. Hansen (2012, p. 165-166), assim como Yates, partilha da ideia de que há um repertório de imagens que o sujeito utiliza para construção da memória, ou seja, as imagens também formam um lugar público, compartilhado. Sobre a relação entre a teoria mnemônica e a teoria do conhecimento aristotélica, tal relação é reconhecida por Yates (2007) em seu estudo pioneiro e motivador dos modernos estudos memorialísticos, $A$ arte da memória. Há que se observar, contudo, que esta relação foi estabelecida pela escolástica e por uma tradição posterior, a renascentista.

3 Apesar da correlação existente entre o pensamento aristotélico e o platônico, Platão não parece fazer tal distinção. Nesse sentido, diferentemente de Aristóteles, Platão parece considerar apenas um modo (o correto, para Aristóteles) de pensar, enquanto as demais sensações não seriam pertencentes ao pensamento, pois referentes à esfera do sensível e não do inteligível.
} 
( entender apenas a parte, haveria também uma divisão entre os modos - correto e incorreto - de pensar. Enquanto o correto seria o entendimento ( $\varphi \rho o ́ v \eta \sigma ı)$ ), a

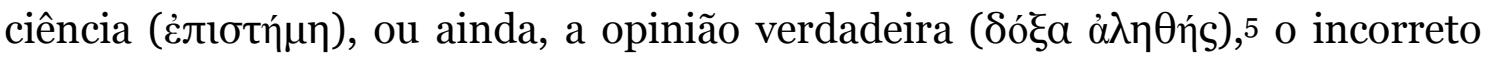
consistiria no mesmo que perceber, uma vez que "a percepção sensível dos sensíveis próprios é sempre verdadeira e subsiste em todos os animais, ao passo

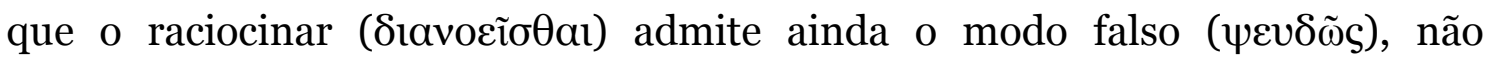
subsistindo naquele que não tem razão ( $\lambda$ óyoc)" (Arist. De an. III, 3, 427a17).

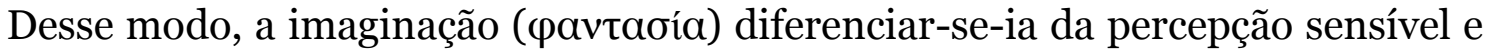
do raciocínio, apesar dela (imaginação) apenas existir por meio da percepção sensível e das suposições. Ao distanciar a imaginação do que seria o pensamento e suposição, Aristóteles nos diz:

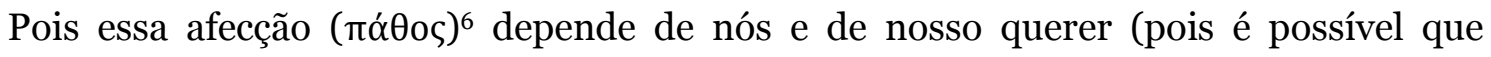
produzamos algo diante dos nossos olhos, tal como aqueles que, apoiando-se na

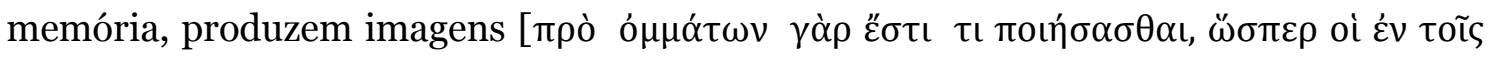

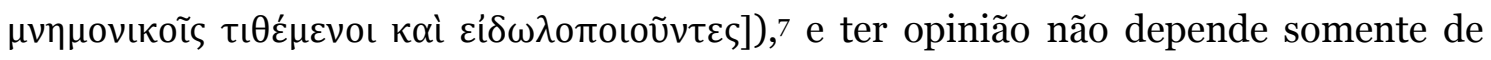
nós, pois há necessidade de que ela seja falsa ou verdadeira (Arist. De an. III, 3, 427b16). Além disso, quando temos a opinião de que algo é terrível ou pavoroso, de imediato compartilhamos a emoção, ocorrendo o mesmo quando é encorajador. Porém, se é pela imaginação, permanecemos como que contemplando em uma pintura ( $\theta \varepsilon \omega ́ \mu \varepsilon v o l$ ćv $\gamma \rho \alpha \varphi \tilde{n})$ coisas terríveis e encorajadoras.

Portanto, a imagem só se formaria por meio da memória e o pensamento devido à imagem. O sujeito, ser dotado de razão, por meio da imaginação, poderia contemplar uma pintura $(\theta \varepsilon \omega ́ \mu \varepsilon v o l ~ \varepsilon ́ v ~ \gamma \rho \alpha \varphi \tilde{n}),{ }^{8}$ uma vez que "para a alma capaz de pensar, as imagens subsistem como sensações

\footnotetext{
4 Constitui-se em consonância à virtude intelectual do sujeito (temperantia, moderatio).

5 Para Aristóteles, a opinião pode ser verdadeira, já para Platão, toda opinião (doxa) é falsa. Portanto, parece haver uma relação e correspondência entre a doxa alethes e os endoxa, discutidos por Aristóteles nos Tópicos (I, 100b18).

${ }^{6}$ A imaginação é pathos (afecção), pois percebida, sendo a percepção convertida em memória e relembrada. A imagem conduz à catarse e é ela que altera o juízo.

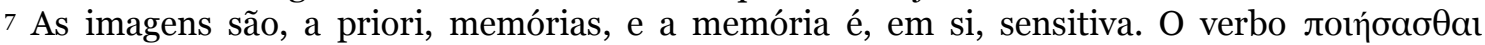
significa fazer, e pertence ao campo artístico, referindo-se, por exemplo, ao fazer estatuária, pintura etc., sendo, portanto, comum ao vocabulário técnico artístico e à discussão platônica e

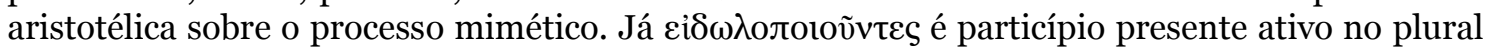
do mesmo verbo e carrega o prefixo de عíkív, simulacro, ou ainda, imagem esvaziada de

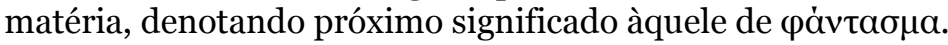

${ }^{8}$ Aristóteles, em De Anima, III, 3, 427b16, novamente usa vocabulário técnico artístico.
} 
percebidas” e, por isso, “a alma jamais pensa sem imagem” (Arist. De an. III, 7, 431a8).

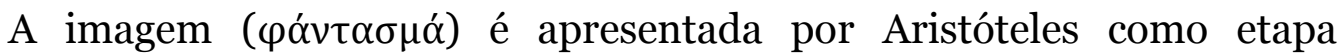

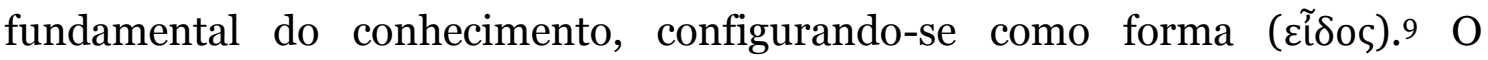
estagirita considera a capacidade de imitar análoga à de imaginar e, assim, encara a imaginação em equivalência à mimesis. Aristóteles, no que poderíamos encarar como quase uma resposta a Platão, nos fornece uma definição para imagem:

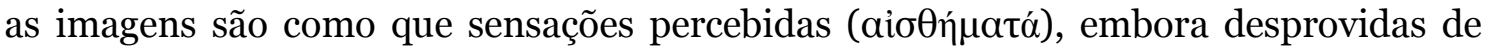

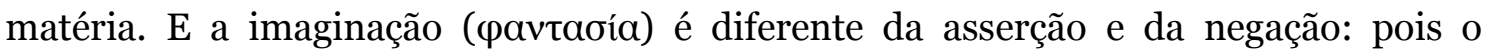
verdadeiro e o falso são uma combinação de pensamentos. Em que os primeiros

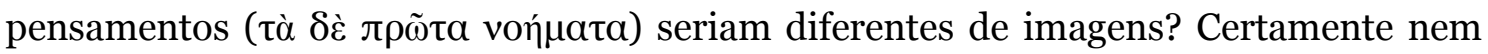
estes e nem os outros pensamentos são imagens, embora também não existam sem imagens (Arist. De an. III, 8, 432a3).

O estudo sobre a história da arte clássica da memória requer, como lembra Yates (2007, p. 18), reconhecer a ars memoriae como pertencente à retórica. As definições platônicas e aristotélicas são importantes para a construção dessa perspectiva, pois são pilares da tradição retórica e, por sua vez, do pensamento sobre a memória e arte antiga que, como veremos, reaparece no Satyricon. É reconhecido que a Antiguidade, imbuída em cultura oral, tinha na memória treinada função fundamental.

Embora outros autores antigos - Quintiliano e Cícero, por exemplo tenham escrito sobre a memória artificial e sua terminologia, inclusive, deixando-nos pistas de que haveria um público leitor familiarizado ao tema, há apenas um tratado sobre a arte clássica da memória. A Rhetorica ad Herennium é a fonte principal sobre o estudo dessa arte e referencia tratados gregos de retórica, possíveis fontes sobre o ensino da memória, mas que não sobreviveram até nosso tempo. Este tratado latino sobre retórica também é o grande responsável pela transmissão da arte da memória, em especial devido à autoridade de Cícero, já que por muito tempo a obra foi atribuída ao Arpinate.

O anônimo autor de Rhetorica ad Herennium, tratando sobre a relação

9 Platão, por outro lado, em sua discussão sobre a mimesis coloca a imagem em um plano rebaixado. 
entre memória e retórica, atribui importante lugar à memória dentro do processo compositivo do discurso retórico. A memória é reconhecida como fundamental para existência da disciplina retórica e definida como "tesouro das coisas inventadas" e "guardiã de todas as partes da retórica" (Auct. ad Her. Rhet. Her. III, 28). O autor também nos explica suas divisões, origem, desenvolvimento e forma:

Nesse assunto, arte e preceito são de muita valia. A nós, parece bem que haja uma arte da memória (artificium memoriae) - o porquê mostraremos alhures; no momento explicaremos como ela é. Existem duas memórias: uma natural, outra produzida pela arte. Natural é aquela situada em nossa mente e nascida junto com o pensamento; artificial é aquela que certa indução e método preceptivo consolidam. Porém, como em tudo mais, é frequente a aptidão do engenho imitar a doutrina, e a arte, por sua vez, fortalecer e aumentar a comodidade natural (Auct. ad Her. Rhet. Her. III, 28).

A Rhetorica ad Herennium exibe constante diálogo com Aristóteles, anunciando o enlace entre a tradição retórica perpetuada concomitantemente à ars memoriae. $\mathrm{O}$ anônimo discute as imagens, que no pensamento platônicoaristotélico já aparecia em dependência da memória ${ }^{10}$ e traz informações sobre a mnemotécnica e o procedimento retórico, assemelhando-os por dependerem dos lugares (loci):

A memória artificial constitui-se de lugares e imagens (loci et imagines). Chamo lugar aquilo que foi encerrado pelo homem ou pela natureza num espaço pequeno inteira e distintamente, de modo que possamos facilmente percebê-los e abarcá-lo com a memória natural: como uma casa, um vão entre colunas, um canto, um arco e coisas semelhantes. Já as imagens são determinadas formas, marcas ou simulacros das coisas que desejamos lembrar. ${ }^{11}$ [...] Os lugares assemelham-se muito a tábuas de cera ou rolos de papiro; as imagens, a letras: a disposição e colocação das imagens, à escrita; a pronunciação, à leitura. Devemos, então, se desejarmos lembrar muitas coisas,

\footnotetext{
10 Em III, 33-37, o anônimo nos diz: "com frequência abarcamos a memória de um assunto inteiro com apenas uma marca, em uma só imagem (imagine simplici)".

11 Estes três são símbolos distintos, mas ambos compartilhados socialmente. As formas (formae/عĩ்os) são o que revestem os conceitos; as marcas (notae) são elementos distintivos que diferenciam sujeitos (mas não são imagens); e os simulacros (simulacra) derivam da

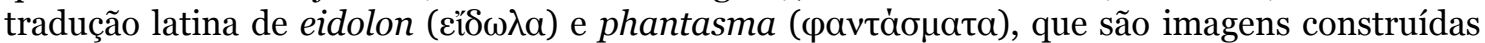
pela mente (simulacros), mas também remetem à imagem esvaída de substância, aproximandose, assim, à ideia de $\varepsilon \check{\delta} \delta \omega \lambda$ ov e ligando-se, portanto, ao vocabulário plástico.
} 
preparar muitos lugares, para neles colocar muitas imagens. Também julgamos que se devam ordenar esses lugares, para não acontecer de, por confundir a ordem, sermos impedidos de seguir as imagens partindo do ponto que quisermos - do começo ou do fim -, e de proferir o que havia sido confiado aos lugares (Auct. ad Her. Rhet. Her. III, 29-30).

Cícero nos diz o seguinte sobre a importância dos lugares na arte da memória:

Aqueles que exercitam esta parte de sua natureza devem pegar lugares e forjar, em sua mente, aquilo que querem guardar na memória e colocá-lo em tais lugares; assim, ocorrerá que a ordem dos lugares conservará a ordem das coisas, enquanto a representação das coisas marcará as próprias coisas, e usaremos os lugares como a cera, os simulacros, como as letras (Cícero. De oratore, II, 354).

Ainda sobre o pensamento de autores romanos sobre a memória, assim como o reconhecimento que fazem da sua relação com retórica, temos a narrativa que Cícero fez sobre a famosa história de Simônides. ${ }^{12}$ No De Oratore, obra concluída possivelmente em 55 a.C., Cícero trata das cinco partes da retórica, indissociavelmente discutindo a mnemotécnica, considerando-a baseada nas mesmas técnicas que encontramos descritas na Rhetorica ad Herennium. Hansen (2012, p. 167) indica a importância do relato de Cícero, uma vez que o latino reconhece a "função retórica atribuída à memória artificial”. ${ }^{13}$ Yates (2007, p. 35) recorda que, apesar do erro ao atribuir a autoria

12 É a lenda fundadora da mnemotécnica antiga, como o próprio Cícero (De or. II, 351-353) nos diz. Ela representa a origem de toda a reflexão sobre a memória artificial e seu treinamento. Para os modernos, também é o onde se inaugura a ars memoriae.

13 "Quando conta a história sobre Simônides, Cícero diz que Temístocles, o Velho, famoso pela sabedoria e inteligência, foi procurado por um sábio que se ofereceu para lhe ensinar o segredo da memória artificial que tinha sido recentemente inventada por Simônides. Temístocles perguntou ao velho qual era a utilidade dessa arte; ele respondeu que era a de lembrar todas as coisas (lugares). Cícero afirma que Temístocles disse que ficaria mais convencido se lhe ensinasse o segredo de esquecer à vontade (Cic. De or. II, 74). Aqui aparece a função retórica atribuída à memória artificial. Antônio, personagem de De Oratore, diz que não tem o engenho de Temístocles para dispensá-la e que é muito agradecido ao velho Simônides, pois recorre a ela para achar os loci que aplica na invenção, na memorização e na ação de seus discursos (Cic. De or. II, 86). A Ars Memoratiua ensina a lembrar elementos do discurso, como coisas, res, noções e argumentos; e palavras, uerba; e também partes do discurso, como as da sua disposição como exórdio, narração, peroração, conclusão; e seus membros gramaticais, orações simples, orações justapostas, períodos compostos, prótases, apódoses; e seus ornatos, metáforas, alegorias, sinédoques, hipérbatos, ironias etc. Cícero diz que todos os ornamentos do estilo que têm mais força e aprovação e todos os que têm beleza para a invenção das ideias se relacionam com os 
da Rhetorica ad Herennium a Cícero, a tradição medieval acertou ao propor que o latino praticava e recomendava a arte da memória.

Yates (2007, p. 36-37) observou o curioso uso feito por Cícero da palavra persona, quando o latino trata dos temas da imagem e da memória em descrição dos procedimentos próprios da mnemotécnica e do discurso retórico. ${ }^{14}$ A autora questiona (Yates, 2007, p. 36-37): "será que esse uso implica que a imagem de memória obtém um efeito impressionante ao exagerar seu aspecto trágico ou cômico, assim como faz o ator ao utilizar uma máscara?” Yates continua a indagação:

[...] esse uso [singulis personis] sugere que a cena teatral era uma fonte verossímil de imagens de memória impressionantes? Ou a palavra significa, neste contexto, que a imagem de memória é como um indivíduo que conhecemos, como adverte o autor do Ad Herennium, ${ }^{15}$ mas que veste aquela máscara pessoal apenas para estimular a memória?

\section{Cena Trimalchionis}

O questionamento de Yates nos fornece elementos para iniciarmos um caminho interpretativo para a análise da construção de imagens na narrativa do Satyricon. A figuração do personagem ficcional de Petrônio, Trimalquião, em capítulos da obra, apresenta-se como um interessante exemplo que pode ser

\footnotetext{
lugares-comuns armazenados na memória”. (Hansen, 2012, p. 167)

14 "A memória para palavras, que para nós é essencial, distingue-se por uma grande variedade de imagens (em oposição ao uso da imagem de uma palavra para toda uma oração ou período, sobre o que ele acabou de falar); pois há muitas palavras que servem como articuladoras, ligando as orações de um período, e estas não podem ser construídas a partir de qualquer uso das similitudes - destas, temos de moldar imagens que sirvam para um emprego constante. Mas a memória para coisa é a propriedade especial do orador - esta nós podemos gravar em nossas mentes, por meio de engenhoso arranjo das várias máscaras (singulis personis) que representam coisas, de modo que possamos apreender as ideias por meio de imagens e a sua ordem". (Cic. De or. II, LXXXVIII apud Yates, 2007, p. 36)

15 Yates faz referência ao exemplo citado na Rhetorica ad Herennium, quando o anônimo elucida como somente uma marca, que utiliza do que é comum (conhecido e compartilhado socialmente), pode figurar uma única imagem a fim de remeter a um assunto inteiro: "o acusador diz que um homem foi envenenado pelo réu, argumenta que o motivo do crime foi uma herança e acrescenta que houve muitas testemunhas e cúmplices. Se quisermos lembrar disso prontamente, para fazer a defesa com desenvoltura, colocaremos, no primeiro lugar, uma imagem referente ao caso inteiro: mostraremos a própria vítima, agonizante, deitada no leito. Isso se soubermos quais são suas feições; se não a conhecermos, tomaremos um outro como doente, mas não de posição inferior, para que possa vir à memória prontamente. E colocaremos o réu junto ao leito, segurando um copo com a mão direita, tábuas de cera com a esquerda e testículos de carneiro com o dedo anular. Assim conseguiremos lembrar das testemunhas, da herança e da morte por envenenamento". (Auct. ad Her. Rhet. Her. III, 33-37) A pele de carneiro, usada para fazer bolsas, faz referência à herança e testículos fazem referência, no latim, à palavra testemunha.
} 
trabalhado com relação à ação do orador de forjar imagens, baseadas em uma memória compartilhada. O personagem, já que um retrato literário, só pode ser compreendido enquanto reconhecidamente construído (pelo autor) e, portanto, identificado (por seu público leitor) por meio de imagines amplamente compartilhadas. Toda a Cena Trimalchionis é uma detalhada descrição do narrador Encólpio sobre as coisas que vê e ouve durante o jantar. A descrição de Trimalquião é completamente harmoniosa com a descrição que Encólpio faz de sua casa. O liberto é pintado no Satyricon, segundo o personagem Encólpio, como velho, careca, vestido com roupas de cores chamativas, acessórios extravagantes e adota uma postura de ostentação e autoelevação sobre a riqueza e posição social que atingiu:

Nós estávamos no meio desse luxo, quando Trimalquião foi trazido para junto da orquestra e, colocado entre minúsculas almofadas, arrancou o riso daqueles que foram surpreendidos pela cena. Ela havia coberto a cabeça raspada com um manto avermelhado e, em volta do pescoço sobrecarregado de pano, ele tinha colocado um guardanapo guarnecido de uma larga banda de púrpura com franjas que caíam de um lado e de outro. Tinha também no dedinho da mão esquerda um grande anel dourado, e também um menor na última articulação do dedo anterior, ao que parecia, todo ouro, mas completamente soldado com peças de ferro em forma de estrelas. E como se não bastasse exibir todas essas riquezas, ele deixou à mostra o braço direito enfeitado com um bracelete de ouro e com uma argola de marfim, fechada com uma lâmina brilhante. (Petrônio, Satyricon, 32, 1-4)

A descrição de Encólpio apresenta o que é visto durante o banquete como escandaloso e inesperado, lembrando que todo o ocorrido relaciona-se a Trimalquião e é controlado pelo mesmo. O narrador demonstra um julgamento sobre o anfitrião, muitas vezes não compreendendo o que é falado e visto, classificando o que vê e ouve como distante do refinamento e elegância. Entretanto, percebemos que o motivo da incompreensão de Encólpio sobre o que se passa é claro: a plateia de Trimalquião divide-se entre os libertos convidados - ricos ou pobres - e os escravos da casa, ambos apresentando subordinados ao anfitrião ${ }^{16}$ e, de outro lado, quatro personagens com formação erudita. Encólpio (narrador/personagem), Ascilto, Gitão e o mestre Agamenon

${ }^{16}$ Os convivas, todos libertos, assim como os escravos, chamam Trimalquião de dominus. 
parecem compartilhar um código social diferente daquele comum à outra parcela da audiência de Trimalquião. No entanto, o próprio anfitrião parece tentar exibir constantemente filiação aos códigos sociais que estes apresentam. Portanto, o liberto, que atingiu imensa riqueza, tenta associar-se indecorosamente a distintos códigos sociais, causando em Encólpio e seus colegas grande desentendimento que lhe causam vergonha.

Quando Encólpio, Ascilto, Gitão e Agamenon entram na mansão do anfitrião, é descrita a figura de um cão pintada na parede. Tal imagem é uma importante chave para nosso problema, já que Encólpio assume, com sua descrição e reação, que há um apuro técnico na execução das imagens que adornavam a casa: ele se assusta com a imagem do cão, imediatamente ficando constrangido. Tal constrangimento é expresso repetidas vezes ao longo do episódio, inclusive pelos demais protagonistas. Sendo assim, se algo não é compreendido, não é por causa de uma imperfeição da imagem, fisicamente tratada, mas por imperfeições dos arranjos imagéticos que surgiram do entendimento de Trimalquião. De todo modo, o que nos importa é que o público leitor de Petrônio reconheceria este conflito precursor do tom satírico da obra.

Ainda no início do episódio do banquete, Encólpio nos narra as pinturas do pórtico que vê na entrada (já anunciando sua não compreensão) do seguinte modo:

Então, eu resolvi perguntar ao escravo encarregado da guarda do pórtico que figuras eram aquelas que estavam no meio: "A Ilíada e a Odisséia", ele disse, "e um espetáculo de gladiadores de Lenas”. (Petron. Sat. 29, 9)

Essa descrição compõe parte da pintura posta na entrada da casa de Trimalquião, que também descreve a trajetória de ascensão do liberto. Encólpio descreve-nos detalhadamente e tenta interpretar o que conhece (Homero) na forma em que o liberto pintou. Trimalquião mistura na pintura repertórios elevados e rebaixados. A tentativa frustrada de entendimento do narrador, assim como a apresentação de Trimalquião - que sempre se exibe como um mentiroso, anunciando informações improváveis e desconexas - provavelmente geraria o riso. Entretanto, o riso só se torna possível pelo fato de o leitor alvo do Satyricon identificar a gênese da comicidade dessas imagens. Petrônio, desse 
modo, constrói a sistemática descrição do ambiente feita por Encólpio. Nesse sentido, há um paradigma na descrição do cão na parede da mansão do rico liberto. Tal episódio anuncia que parte da descrição é feita por Encólpio, que se constrange por se assustar com a pintura do cão, ou seja, por não compreendêla, e parte é reprodução do que os colibertos afirmam, com exemplo na explicação do porteiro, a quem Encólpio solicita ajuda para interpretar as pinturas que vê no pórtico.

A falta de decoro associada à figura de Trimalquião quando mescla repertórios, assim como toda a incompreensão e vergonha dos protagonistas que não compreendem quase nada do que presenciam, parece tecer críticas a um comportamento indecoroso e desmoderado, possivelmente, associado não só à classe de libertos, mas a todos os segmentos sociais, sobretudo, à aristocracia da sociedade romana do tempo neroniano. ${ }^{17}$ Apesar de vários elementos descritos na casa serem luxuosos, a decoração não respeita o princípio de decoro e mediania esperados - pelo menos no que tange ao discurso de um aristocrata romano do século I d.C. Desse modo, o que o banquete parece transparecer, por meio, principalmente, do personagem do liberto e a reação de parcela da audiência deste, é uma decadência e desmoderação no campo artístico e moral. ${ }^{18}$

Do mesmo modo, ao descrever como deseja seu próprio túmulo e funeral, Trimalquião adota um discurso classificado por Encólpio como de extremo mau gosto, indicando escolhas que também não estão em acordo com um estilo funerário apropriado à aristocracia romana. De fato, o discurso fúnebre que o liberto assume é distante de um comportamento moderado e passível de elogio, segundo a elite romana. Em contrapartida, o liberto exibe dupla filiação, não se apresentando como um aristocrata romano, já que não tem ancestrais nobres, nascimento livre ou um repertório ligado à elite, mas também não se exibe como um liberto, devido à riqueza e aos incomuns

\footnotetext{
${ }^{17}$ A historiografia, sobretudo francesa, associou o personagem com a ideia de nouveau riche, de um parvenu. Contudo, nos parece ultrapassada interpretações nesse sentido, como a de P. Veyne, que analisou o banquete de Trimalquião pensando a sociedade romana de forma hierárquica em uma esfera sociocultural binomial e totalmente apartada.

${ }^{18}$ A falta de mediania é índice, portanto, de falta de mediania moral e viabiliza a ideia do cômico como deformidade, física e do caráter. Tal noção está presente também em Plínio, o Velho, em passagens sobre imagens. A crítica de Plínio é bastanta próxima àquela de Petrônio: a falta de unidade e decoro das imagens são análogas da falta de mediania do caráter dos homens que as possuem.
} 
recursos materiais que alcançou e por se apropriar ainda de códigos culturais e de um repertório que era próprio da aristocracia:

A coisa caminhava para a mais extrema repugnância, quando Trimalquião, sobrecarregado pela mais torpe embriaguez, mandou que se apresentasse na sala de jantar um grupo diferente de músicos, os corneteiros, e, escorado em muitas almofadas, estendeu-se sobre seu leito fúnebre e disse: "Finjam que morri. Digam alguma coisa de belo". Os corneteiros entoaram uma marcha fúnebre. Um escravo em especial, o de seu agente de funerais, que era o mais decente deles, chorou tanto que influenciou todos a sua volta. (Petron. Sat. 88, 5-6)

Esta cena antecede o fim da narrativa do banquete, com a fuga dos personagens da casa e evidencia o caráter da teatralidade que perpassa e estrutura toda a Cena Trimalchionis. Por meio desse caráter teatral é empregada uma série de elementos identificáveis, pois compartilhados socialmente, para o público leitor específico do Satyricon: a aristocracia romana do tempo neroniano. O uso do que é conhecido pela audiência e a identificação que a mesma faz conclui a "técnica de produzir enunciados que têm enargeia, apresentando a coisa quase como se o ouvido a visse em detalhe". (Hansen, 2006, p. 85)

Pensamos que Petrônio, ao criar um personagem por meio de uma caricatura coletiva, como sugeriu Faversani (1999, p. 142-145), ou seja, utilizando vários elementos associados a diferentes classes sociais e reconhecidos amplamente por uma aristocracia romana, 19 cumpre o objetivo de forjar imagens verbais a partir desses lugares comuns compartilhados por grupos sociais, ainda que pela falta de decoro das representações elas servissem para gerar riso. De fato, a identificação dessas imagens sistemáticas de lugares comuns são o que provocam o riso diante da montagem teatral. A obra ciceroniana nos ajuda a formular este tipo de interpretação, pois, como sintetizou Yates:

Cícero nos forneceu um pequeno tratado de Ars memoratiua altamente condensado,

19 "O nome personagem coletivo foi empregado para um tipo de construção literária em que os indivíduos são amalgamados de tal forma que é impossível distingui-los como tais, sendo suas identidades e identificações dadas por um coletivo. Eles não fazem sentido como indivíduos, mas como grupos. É impossível dizer o número de pessoas que compõe cada personagem coletivo". (Faversani, 1999, p. 142) 
em que abordou todos os pontos na sua ordem usual. Iniciou com a afirmação, introduzida pela história de Simônides, de que a arte da memória consiste em lugares e imagens e é como uma escrita interior sobre a cera; ele prossegue e discute as memórias natural e artificial, com a conclusão de praxe de que a natureza pode ser aprimorada pela arte. Então, vêm as regras para lugares e imagens; depois, a discussão sobre a diferença entre a memória para coisas e para palavras. Embora admita que apenas a memória para coisas é essencial ao orador, Cícero testou consigo mesmo a memória para palavras, na qual as imagens para palavras se deslocam(?), mudam de caso(?), levam toda uma sentença a uma única imagem verbal, de uma maneira extraordinária, que ele visualiza interiormente, como se fosse a arte de algum pintor habilidoso. (Yates, 2007, p. 37)

Petrônio parece assemelhar-se ao orador ou ao pintor por criar em sua narrativa imagens, partindo daquilo que seu leitor reconhece. Assim, sua escrita imagética integra a formulação do riso no Satyricon. Entendemos que o recurso petroniano à construção de imagens - socialmente compartilhadas - é também um esforço no campo da memória e, portanto, da retórica. Cícero diz-nos sobre isso que:

Qual seja a vantagem da memória para o orador, quão grande a sua utilidade e a sua força, que necessidade tenho eu de falar? Guardar o que aprendeste ao assumir uma causa, o que tu mesmo refletiste? Ter fixos na mente todos os pensamentos, inteiramente classificado o aparato das palavras? De tal forma ouvir a fonte de tuas informações ou aquele a que se tem de responder, que não pareçam derramar seu discurso sobre teus ouvidos, mas gravá-los em tua mente? (Cic. De or. II, 355).

Ainda na chave da memória, associável ao uso de imagens compartilhadas, já que reconhecidas e risórias no Satyricon, Cícero também diz:

De fato, Simônides, ou qualquer outro que o tenha descoberto (inuenit), foi sagaz ao perceber que se fixa em nossas mentes sobretudo aquilo que é transmitido e marcado pelos sentidos; que o mais aguçado de todos os nossos sentidos é o da visão; que, por isso, pode ser guardado com mais facilidade na mente se, além de percebido pelos ouvidos e pela reflexão, também for transmitido à mente pelo apoio dos olhos; de modo que uma representação, uma imagem e uma forma de tal modo marcariam coisas 
não vistas e afastadas do julgamento da vista, que poderíamos, por assim dizer, guardar pela visão aquilo que mal conseguimos abarcar pelo pensamento. Essas formas e corpos, tal como tudo que cai no domínio da visão, precisa de uma sede; de fato, um corpo não pode ser percebido sem um lugar. Por isso, para que não seja excessivo e desmedido num tema conhecido e trivial, deve-se usar lugares variados, iluminados, claros, a pequenos intervalos, e imagens em ação, vivas (acribus), notáveis (insignitis), que possam ser percorridas com rapidez e penetrar com força na mente (percutere animum). Tal capacidade será fornecida pelo exercício, donde nasce o hábito. Mas a memória das palavras (uerborum memoria), que nos é menos necessária, distingue-se por uma maior variedade de imagens. [...] E não é verdade, como dizem os incapazes, que a memória fica oprimida pelo peso das imagens e que mesmo aquilo que a natureza, por si mesma, poderia guardar, é obscurecido. De fato, eu mesmo pude ver homens excelsos e de memória quase divina [...] diziam escrever, tal como faziam com letras na cera, aquilo de que desejavam lembrar com imagens naqueles lugares que possuíam. Por isso, não se deve arruinar a memória com este exercício se não houver nenhuma por natureza; mas, se está latente, com certeza deve ser excitada. (Cic. De or. II, 357-360)

A Retórica a Herênio, em completo acordo com Cícero, nos diz que "com frequência abarcamos a memória de um assunto inteiro com apenas uma marca, em uma só imagem (imagine simplici)". (Auct. ad Her. Rhet. Her. Ad Herennium III, 33-37)

Sobre o procedimento compositivo das imagens, para entendermos aquelas pintadas no Satyricon e marcadas na memória na chave do risível, indicamos no tratado retórico latino a seguinte passagem:

Devemos, pois, constituir imagens daquele tipo capaz de aderir à memória por mais tempo. Isso ocorrerá se estabelecermos similitudes marcadas o mais possível, se não colocarmos imagens vagas ou em grande número, mas que tenham alguma ação, se lhes atribuirmos especial beleza ou singular fealdade, se ornarmos algumas com coroas ou vestes de púrpura, para tornar a semelhança mais marcante para nós, ou se de algum modo as desfigurarmos, manchando-as de sangue, cobrindo-as de lama ou borrando-as com tinta vermelha, para que sua forma seja mais notável; ou ainda, se atribuirmos às imagens alguns elementos ridículos, pois também isso nos fará lembrar com mais facilidade. As mesmas coisas de que nos lembramos facilmente quando verdadeiras, também lembraremos sem dificuldade quando forem forjadas e 
cuidadosamente marcadas. (Auct. ad Her. Rhet. Her. III, 33-37)

Ao lermos este (único) manual de retórica antiga sobrevivente, podemos ver enorme proximidade entre as imagens forjadas - classificadas como eficientes para a memória - e as construídas narrativamente por Petrônio. A retratação do liberto Trimalquião, a descrição feita por Encólpio de sua casa e todo o discurso fúnebre que o próprio liberto faz, possuem formas notáveis, constituindo-se por elementos do ridículo. O exagero e o ridículo mormente são reconhecidos como construtores do riso. Porém, indicamos tais elementos, no caso da sátira petroniana, como recurso também das imagens de memória.

A descrição que Trimalquião faz de seu próprio túmulo, ao solicitar a construção ao seu amigo Habinnas (Petron. Sat. 71), apresenta-se como uma grande imagem que utiliza de elementos conhecidos, possivelmente com similares podendo ter sido vistos por todos em monumentos espalhados por Roma. Assim como todas as imagens criadas por Petrônio parecem direcionarse a uma crítica da sociedade de seu tempo, a temática funerária apresentada no discurso que o liberto faz de seu monumento parece ridicularizar a suntuosidade e riqueza percebida em túmulos romanos. Todavia, mesmo a sátira petroniana se apresentando como crítica ampla à sociedade romana, no tema fúnebre a crítica parece direcionar-se especificamente ao menor refreamento no autoelogio típico de libertos que atingiram certa ascensão social, uma vez que a elite romana comumente adotou como exemplar à época um novo idioma de simplicidade e modéstia. Bandinelli (1970, p. 64-105, 177-202, 212-221), autor marxista crítico de arte, acusa a iconografia do túmulo de Trimalquião de plebeia e essa ars plebeia, encontraria um paralelo na sermo pauperorum (forma de expressão) de libertos: aspectos linguísticos e artísticos determinados pela classe social. Mouritsen (2005, p. 56-57) revisou tais ideias ao falar sobre o monumento de Trimalquião:

Esse monumento sugere uma forte preocupação com honras públicas e auto comemoração [...] monumentos de libertos e inscrições geralmente revelam um grau mais forte de estado de consciência e competição que os monumentos da elite. A importância da comemoração funerária é sublinhada pelo fato de que muito mais libertos encomendaram seus monumentos do que fizeram membros da elite [...] enquanto a elite pode deixar referências às suas honras e ofícios, libertos poderiam ir a 
consideráveis proporções para garantir que eles fossem recordados [...] libertos, assim, desenvolveram normas e práticas epigráficas que contrastaram nitidamente com aquelas da elite.

De todo modo, independente do tom crítico da sátira e de quaisquer que sejam os direcionamentos das críticas petronianas, estas imagens associadas ao liberto rico, à sua casa e monumento funerário são forjadas por meio de lugarescomuns próprios da representação na Antiguidade. De acordo com Hansen (2012, p. 167), "Cícero diz que todos os ornamentos do estilo que têm mais força e aprovação e todos os que têm beleza para a invenção das ideias se relacionam com os lugares-comuns armazenados na memória”. Assim, as imagens da Cena Trimalchionis são eficientes, tanto no que se refere ao riso quanto à retórica e a memória, uma vez que:

As imagens dos lugares-comuns também pressupõem elocução adequada, ou seja, palavras adequadas, pois eles se opõem ao esquecimento e à morte, manipulando o "fantasma da sua reaparição" [...]. A manipulação do fantasma deve trabalhar com imagens extremamente vívidas, intensas e "coloridas", muitas vezes cômicas, ou exageradas, deformadas, sujas e horríveis, que impressionam fortemente a imaginação e a memória. A imagem intensa é mais eficaz porque efetua pathos, paixão e compaixão, atingindo a imaginação com "vividez" (enargeia; euidentia). (Hansen, 2012, p. 167).

Entendemos que Petrônio, ao construir imagens, mobiliza as mesmas dos lugares de memória e as coloca em remodelados lugares da memória, considerando que:

Um locus é um lugar facilmente apreendido pela memória, como uma casa, um intercolúnio, um canto, um arco etc. Imagens são formas, signos distintivos, símbolos (formae, notae, simulacra) daquilo de que queremos nos lembrar [...]. A arte da memória é como uma escrita interior. Os que conhecem as letras do alfabeto podem escrever o que lhes é ditado e ler o que escreveram. Do mesmo modo, aqueles que aprenderam a mnemônica podem colocar em lugares específicos aquilo que ouviram e falar de memória. "Porque os lugares são como tábuas de cera ou como papiros, as imagens são como letras, o arranjo e a disposição das imagens são como a escrita, e o fato de pronunciar é como a leitura”. (Yates, 2007, p. 23) 


\section{A crítica da arte em Petrônio e Plínio, o Velho}

Por meio das imagens construídas percebemos na obra petroniana, como já dito, um movimento narrativo direcionado à crítica social. Este movimento aproxima-se do que diz outro autor latino do século I, em sua importante obra, repleta também de críticas, ironias e informações sobre a arte antiga. Plínio, o Velho, tece crítica à arte na Roma de seu período, acusando o altíssimo desenvolvimento da técnica e da riqueza dos materiais usados, segundo o autor, que causaria a apreciação mais do material do que da representação em si. Plínio também critica o efeito cada vez maior de técnicas e estilos estrangeiros, principalmente do helenístico, que rebaixariam a arte romana tradicional. Nesse sentido, na História Natural de Plínio, há uma denúncia da decadência da arte romana tradicional, então associada ao retrato realista. Plínio parece repudiar especificamente as estátuas cujas cabeças eram trocadas. Notamos, por meio do texto pliniano, que haveria uma crescente vulgarização da retratística e, concomitantemente, difusão de pinacotecas.

Em primeiro lugar, trataremos de tudo que resta acerca da pintura, arte nobre outrora - pois que era, então, cobiçada por reis e nações - que, ao celebrizar alguns, tornava-os dignos de serem legados à posteridade. ${ }^{20}$ Agora, porém, foi inteiramente superada pelos mármores, decerto já também pelo ouro - nem tanto para que as paredes todas fossem cobertas -, e ainda pelo mármore esculpido em baixo relevo e pelos mosaicos feitos para acomodar imagens de coisas e de animais. ${ }^{21}$ Ábacos já não agradam, nem aqueles espaços que, amplos, espalham montanhas nos aposentos de dormir; começamos até a pintar na pedra. ${ }^{22}$ [...] São estas as coisas que servem de subsídio para aqueles montes que nos faltam à vista, nem a exuberância cessa de fazê-lo, para que a maior quantidade possível deles se perca nos incêndios. Sem dúvida, a pintura de retratos, por meio da qual eram legadas para a posteridade figuras maximamente semelhantes, desapareceu de todo. Escudos de bronze são colocados em face argêntea com oculta diferença entre as imagens; as cabeças das estátuas são trocadas, como propagado já há algum tempo ainda pelos gracejos dos poemas. Por causa disso, todos

\footnotetext{
${ }^{20}$ Arte enquanto como poesia, retórica etc., remetendo à té $\chi \vee \eta$.

21 É empregado termo técnico (interraso marmore) para baixo relevo. Plínio usa constantemente um vocabulário técnico artístico, de modo que essa parcela de sua obra se constitui como uma espécie de tratado artístico, único sobrevivente.

${ }^{22}$ Critica pintura de afrescos, em parede, e eleva quadros, mas tal tipo de obra não nos chegou. Porém, sabe-se que os pintores de afrescos incorporaram técnicas da pintura em quadros.
} 
preferem observar o material do que reconhecer o figurado. E, em meio a tudo isso, as próprias pessoas - não atribuindo valor algum a não ser pelo preço - costumam adornar galerias com antigas telas e cultuar bustos alheios, para que um herdeiro os destrua e, com um laço, arraste-os para fora. Nesse sentido, uma vez que não se conserva efígie de ninguém, deixam imagens do dinheiro, não suas. [...] A indolência pôs a perder as artes; visto que não há imagens do espírito, negligenciam também as do corpo. ${ }^{23}$ Diferentemente, no tempo de nossos antepassados, estes mesmos retratos costumavam ficar nos átrios, a fim de que fossem contemplados; não havia obras de artistas estrangeiros, nem bronzes, nem mármores: modeladas a partir da cera, suas feições eram dispostas em nichos individuais, para que houvesse imagens (imagines) que acompanhassem o cortejo fúnebre dos nobres (gentilicia funera); ${ }^{24} \mathrm{e}$, sempre no exício de alguém, toda a gente que houvera um dia daquela família estaria presente. Os valores de estirpe, verdadeiramente, atravessavam, em seus contornos, as imagens pintadas, e os arquivos eram plenamente providos com livros e monumentos dos feitos empreendidos nas magistraturas (monimentis rerum in magistratu gestarum). ${ }^{25}$ (Plínio, Naturalis historia, 35)

Esta passagem, apesar de indicar a existência de um menosprezo contemporâneo quanto à produção artística relacionada à pintura do tempo em que viveu Plínio, nos indica mais informações. Há uma ideia que podemos interpretar em Plínio: a glória associada à arte se aplica tanto àquele representado - na pintura, enquanto retrato ou feito -, mas também compreende o próprio artista. Este atingiria o triunfo e, consequentemente, a imortalidade. Nesse sentido, o pintor poderia torna-se tão imortal quanto o poeta, perpetuando sua memória através de sua obra. ${ }^{26}$

Encontramos no Satyricon uma concordância explícita com a crítica à decadência da arte, tema de proêmio visto na obra pliniana e também confirmação à denúncia da proliferação de galerias de arte. Há, assim, um tema em comum entre as duas fontes, relativo à arte ou à valoração que se dá à arte.

\footnotetext{
23 Imagens dos antepassados.

24 As máscaras funerárias tinham importante papel no funeral romano aristocrático. Os columbários eram formados por nichos e, nas casas aristocráticas, amplificava a memória e poder da família de mortos ilustres. Quanto maior e mais triunfal o cortejo, maior o poder da gens e Plínio parece estar criticando que isto já não mais existia quanto e como antes, ou que, mesmo existindo, não era mais tão valorizado em seu tempo. Ele reconhece um caráter moralizante dessas "verdadeiras" imagens romanas, já que os rostos desses aristocratas antecipavam as virtudes dos mesmos.

${ }^{25}$ Esses arquivos são os espaços das salas à entrada das casas da elite romana.

${ }_{26}$ Neste ponto, Plínio parece contribuir para uma aproximação da pintura à poesia, como encontrado em Horácio.
} 
No episódio que se passa em uma pinacoteca, Encólpio dialoga com Eumolpo, um personagem que surge nesse momento da história, retratado como um velho careca, muitas vezes criticado socialmente e até mesmo apedrejado. Encólpio narra:

[...] Entrou na galeria de artes um velho de cabelos brancos, de ar perturbado, que parecia anunciar não sei o quê de importante, mas inversamente proporcional à sua maneira deselegante de se vestir, pois ele mostrava claramente que era daquela espécie de letrados que os ricos costumam odiar. Ele então parou do meu lado. "Eu", disse ele, "sou poeta e, assim espero, não um poeta de humílima inspiração, se pelo menos se pudesse dar algum crédito às coroas que, por sua amizade, costumam-se conceder até mesmo os inábeis. Você deve estar dizendo: 'Por que, então, você se veste tão mal? Exatamente pela seguinte razão: o amor pela habilidade intelectual nunca fez ninguém mais rico'. ${ }^{27}[. .$.$] Não há dúvida de que seja assim: se alguém, inimigo de todos os vícios,$ resolve dedicar-se ao caminho correto da vida, ele atrai em primeiro lugar a antipatia dos outros, por causa da diferença de costumes [...] assim, perseguem, por qualquer motivo que conseguem, os amantes da literatura, para que também eles se mostrem colocados abaixo do dinheiro". "Não sei como, mas a pobreza é irmã do bom caráter". (Petron. Sat. 83, 7-8; 84, 1-4)

Na História Natural, percebemos o traço moralizador do autor por meio da crítica e anúncio de decadência de seu tempo - que talvez reflita a perspectiva aristocrática. Assim como no Satyricon, há uma visão negativa do presente, que estaria distanciando-se progressivamente dos valores artísticos e morais tradicionais. Ambas as fontes, denotam a ideia de que a verdadeira pintura possuiria valor monumental - obedeceria a um decoro "monumental" e ainda mais: não se banalizaria. Considerando a importância fundamental da pintura e artes plásticas em geral para a noção de memória antiga, é interessante remetermos à ideia de monumento proposta por Le Goff (2007, p. 535-536):

A palavra latina monumentum remete para a raiz indo-europeia men, que exprime uma das funções essenciais do espírito (mens), a memória (memini). O verbo monere

${ }^{27}$ Logo em seguida, Eumolpo recita um interessante poema que mereceria um estudo particular, mas basta-nos agora saber que trata-se de uma clara denúncia da relação entre o amor ao ouro e a decadência moral e artística. 
significa "fazer recordar", de onde "avisar", “iluminar", “instruir". O monumentum é um sinal do passado. Atendendo às suas origens filológicas, o monumento é tudo aquilo que pode evocar o passado, perpetuar a recordação, por exemplo, os atos escritos. Quando Cícero fala dos monumenta huius ordinis [Philippicae, XIV, 41], designa os atos comemorativos, quer dizer, os decretos do senado. Mas desde a Antiguidade romana o monumentum tende a especializar-se em dois sentidos: 1) uma obra comemorativa de arquitetura ou de escultura: arco de triunfo, coluna, troféu, pórtico, etc.; 2) um monumento funerário destinado a perpetuar a recordação de uma pessoa no domínio em que a memória é particularmente valorizada: a morte. O monumento tem como características o ligar-se ao poder de perpetuação, voluntária ou involuntária, das sociedades históricas (é um legado à memória coletiva) e o reenviar a testemunhos que só numa parcela mínima são testemunhos escritos.

Com esta definição, podemos entender a arte antiga enquanto monumentum. Neste sentido, a imagem ainda pode ser pensada enquanto memória. O estudo histórico da arte da memória clássica requer a leitura competente de inúmeras fontes que compõe uma história possível da ars memoriae. Entretanto, estas fontes não se findam no legado literário das elites gregas e romanas. Reconhecer a importância da cultura material - sobretudo àquela relacionada ao âmbito da morte - como vestígio da memória, causa a ampliação de nossas possibilidades de acesso ao passado. Desse modo, pensamos que o exercício - pautado inclusive nas investidas similares dos próprios antigos - de relacionar a retórica, a memória e a arte antiga, pois pertencentes à mesma esfera, significa reconhecer que o passado do qual tratamos é bem mais complexo do que já se pensou e protagonizado por sujeitos tão versados quanto àqueles que se inclinam a este passado. 


\section{REFERÊNCIAS BIBLIOGRÁFICAS}

\section{Fontes Primárias}

[Anônimo] Retórica a Herênio. Tradução de Ana Paula C. Faria e Adriana Seabra. São Paulo: Hedra, 2005.

Aristóteles. De Anima. Apresentação, tradução e notas de Maria Cecília Gomes dos Reis. São Paulo: Editora 34, 2006.

Cícero. Sobre o Orador. Tradução de Adriano Scatolin. Tese de Doutorado, Letras Clássicas, Faculdade de Filosofia, Letras e Ciências Humanas - FFLCH, Universidade de São Paulo, 2009.

Petrônio. Satyricon. Tradução de Sandra M. G. B. Bianchet. Belo Horizonte: Crisálida, 2004.

Platão. Fedro ou Da Beleza. Tradução e notas de Pinharanda Gomes. $6^{\mathrm{a}}$ edição. Lisboa: Guimarães Editores, 2000.

Pliny, The Elder. Natural History. With an English translation by D. E. Eichholz. Cambridge/London: Havard University Press, vol. X: books 35-36, 1962.

Tácito. Anais. Tradução de J. L. Freire de Carvalho. São Paulo: Ed. W. M. Jacksonville Inc., 1964.

\section{Bibliografia Crítica}

Bandinelli, B. R. Rome: The Center of Power. Trans. Peter Green. New York: Brazziller, 1970.

Faversani, F. A Pobreza no Satyricon de Petrônio. Ouro Preto: Editora da UFOP, 1999.

Hansen, J. A. Categorias epidíticas da ekphrasis, Revista da USP, n. 71, 2006, p. 85-105.

. Lugar-comum. In: Muhana, A.; Laudanna, M.; Bagolin, L. A. (orgs) Retórica. São Paulo: Annablume Editora/IEB-USP, 2012, p. 159-177.

Le Goff, J. Documento/Monumento. In: História e Memória. Campinas, Campinas: Editora da Unicamp, 1990, p. 535-549.

Mouritsen, H. Freedman and decurions: Epitaphs and social history in Imperial Italy, JRS, 95, 2005, p. 38-63.

Yates, Francis A. A Arte da Memória. Tradução de Flávia Bancher. Campinas: Editora da Unicamp, 2007. 